\title{
Preventive Effect of Gliclazide on Experimental Atherosclerosis in Rabbits
}

\author{
G. Marquié \\ Department of Nutrition, Institute of Biology, University of Science and Technology, Algiers, Algeria
}

\begin{abstract}
Summary. Administration of a hypoglycaemic sulphonamide, gliclazide, at $10 \mathrm{mg} / \mathrm{kg} /$ day p.o. to rabbits for 60 days did not affect the development of plasma lipid disturbances induced by a high cholesterol diet. The accumulation of cholesterol in the liver was significantly reduced by up to $34 \%$ when compared with animals on the high cholesterol diet. The high concentrations of glycerides and fatty acids in the aorta were significantly decreased towards normal values and histology showed that the gliclazide strongly inhibited the development of aortic and particularly coronary lesions induced by the atherogenic diet. A normal appearance of coronary arteries was noted in more than $50 \%$ of cases.
\end{abstract}

Key words: Plasma, fatty liver, atherosclerosis, coronary cholesterol, sulphonylureas, gliclazide, rabbit.

The longer survival of diabetic patients has revealed a high incidence of vascular complications involving either arteries or capillary bed or both. Sulphonylureas have been used to control blood glucose.

Concomitant treatment of arterial disease with the earlier hypoglycaemic sulphonamides produced controversial results at both the experimental and clinical levels. Punsar and Hartel [29] and Hartel et al. [16] showed that carbutamide can have a hypercholesterolaemic effect and can aggravate experimental and spontaneous atherosclerosis in chickens, the frequency of coronary lesions in particular being greatly increased. These results were also confirmed by the use of high doses of chlorpropamide in rabbits subjected to an atherogenic diet [23]. Chlorpropamide appeared to inhibit the elimination of the excess fat in atherosclerotic lesions, following termi- nation of the atherogenic diet [24]. At the clinical level, the enquiry by the U.G.D.P. [1 and 2] concluded that long term therapy with tolbutamide had adverse effects on cardiovascular complications. On the other hand, Keen and Jarrett [19] recently gave a report on the beneficial effect of using tolbutamide in hyperglycaemic patients. Paasikivi and Wahlberg [28] came to the same conclusions. Under these circumstances, we thought it appropriate to investigate experimentally whether gliclazide could affect the development of arterial lesions induced in the rabbit by a diet enriched with cholesterol.

\section{Materials and Methods}

Experiments were conducted over a period of two months on 52 fawn Bourgogne rabbits each weighing approximately $3 \mathrm{~kg}$. Eighteen rabbits received no treatment, 18 rabbits were given $400 \mathrm{mg}$ of cholesterol (with no oily excipient) per body wt daily, and the remaining 16 rabbits received, in addition to the cholesterol, $10 \mathrm{mg}$ per $\mathrm{kg}$ body wt per day of gliclazide orally in two doses. The food allowance was $150 \mathrm{~g}$ per day in the form of commercial granules for rabbits, and water was given ad libitum. The weight curve for rabbits treated with gliclazide was comparable to that for the control rabbits and the animals to which only cholesterol was administered.

All sacrifices were performed simultanéously to escape bias resulting from seasonal effects.

The chemical structure of gliclazide is:

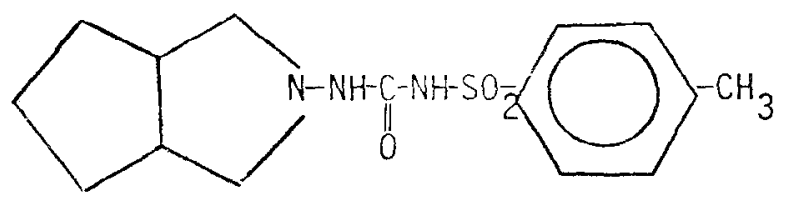


For plasma lipid determination, venous blood samples were collected from the rabbit's ear after the 15 th, 30 th, 45 th and 60 th days of treatment between 9 and 11 a.m.

Slices of aorta were homogenised with a mixture of chloroform methanol $(2: 1$ by volume) within a virtis apparatus.

Extraction of the plasma or tissue lipids was carried out in accordance with the method of Folch et al. [12]. The quantity of total fatty acids was determined by a micro-method developed from the works of Sperry and Brand [32], Folch et al. [12] and Albrink [3]; total cholesterol by the colorimetric method of Lieberman-Burchard. Phospholipids were determined by a method developed from Delsal and Manhouri [4], followed by quantitative colorimetric determination [10]. Free fatty acids were measured by the method of Laurell and Tibbling [21] and plasma glucose by the method of Somogyi [30]. The quantitative composition of the plasma and liver in terms of triglycerides, cholesterol esters and free cholesterol was determined by chromatography separation on a column packed with a mixture of silic acid and supercell [17]. Lipid separation by thin layer chromatography according to Landiscrina et al. [20] followed by densitometer quantification gave similar figures.

Macrocospic assessment of the degree of aortic atherosclerosis was made for each animal over the entire arterial trunk in accordance with the usual criteria which enable a distinction to be drawn between 5 stages $-0,1,2,3$ and 4 [27]: $0=$ normal artery; 1 = fatty streaks and small plaques up to $10 \%$ of the aortic area; $2=$ plaques covering $10-25 \%$ of the aorta; $3=$ plaques extending over $25-50 \%$ of the area; $4=$ from $50 \%$ to complete involvement. Samples were taken of the arch of the aorta, the thoracic aorta, the abdominal aorta and the myocardium for the purpose of histopathological examination. The tissues were stained with Masson's trichrome and Verhoeff's iodised haematoxylin in order to confirm the degree of modification of the elastic fibres. The presence and extent of the arterial lesions was evaluated against an atherosclerosis scale ranging from 0 to $4[13]: 0=$ normal artery; $1=$ disorganization in connective tissue (collageneous increase and superficial elastic degeneration); 2 = lipid infiltration (thickening of sub-endothelial space with appearance of foam cells and numerous fibres of collagen); $3=$ extensive lipid plaques (the internal elastic limiting membrane was fragmented, the internal zone of the tunica media consisted of smooth muscle cells invaded by lipids scattered elastic elements and disordered collagen fibres, the external zone of the tunica media and the adventiti- ous tunica were not affected); $4=$ converging lipid plaques.

Samples of the thyroid gland were taken and stained with Masson's trichrome and thyroid activity assessed on Kampelmann's scale [18]. The degree of thyroid activity was classified from 1 to 5 : Stage 1 , the vesicles were of small diameter, the colloid very sparse, the nuclei rounded and located halfway up the cell, the gland strongly vascularized; stage 2 , the vesicles were rather small, the colloid sparse, the epithelium with a central nucleus, the gland was well vascularized; stage 3 , the thyroid vesicles were of medium size, the colloid became abundant, the epithelium cubic, the vascularization remained important; stages 4 and 5, the vesicles were of great diameter, the colloid abundant or very abundant and acidophilic, the cells of the thyroid epithelium flat and their nuclei oval and attached to the base, vascularization was poor.

The data were analysed statistically using Student's $t$ test. The mean values and standard error of the mean are given in tables. The criterion for statistical significance is $p \leqslant 0.05$.

\section{Results}

\section{Effect of Cholesterol Rich Diet Alone}

Plasma and Liver Lipids: The rabbits to which only cholesterol was administered showed marked hyperlipaemia especially of cholesterol esters. The content of esterified cholesterol reached $910 \pm 70 \mathrm{mg}$ / $100 \mathrm{ml}$ on the 60 th day of the diet as compared to 21 $\pm 2 \mathrm{mg} / 100 \mathrm{ml}$ for the same animals before treatment. There was a slow, but progressive increase in plasma free fatty acids. The plasma glucose values were unchanged (Table 1). An increase in liver mass was observed, the lipid surplus being considerable at the end of the experiment; the contents of free and esterified cholesterol were particularly high, with those of phospholipids and glycerides increasing to a lesser degree (Table 2)

Arterial Lipids: In cholesterol-fed rabbits, there were large lipid accumulations involving cholesterol more than phospholipids or triglycerides. Cholesterol content was approximately ten times higher than in control animals (Table 3).

Arterial Pathology: Macroscopic lesions were generalised over the entire arterial trunk and characterised by extensive lipid deposits, frequently converging at the level of the arch of the aorta (Table 4).

Histopathological examination of these 'lipid pla- 
Table 1. Evolution of plasma lipids in cholesterol fed rabbits - effects of gliclazide

\begin{tabular}{|c|c|c|c|c|c|c|}
\hline \multirow[t]{2}{*}{ Biochemical analysis } & \multirow{2}{*}{$\begin{array}{l}\text { Treatment } \\
\text { period } \\
\text { (days) }\end{array}$} & \multicolumn{5}{|l|}{ Group } \\
\hline & & Normal control [18] & $\begin{array}{l}\text { Cholesterol } \\
{[18]}\end{array}$ & ed rabbits & $\begin{array}{l}\text { Cholesterol fe } \\
\text { Gliclazide [16 }\end{array}$ & d rabbits + \\
\hline Total fatty acids $(\mathrm{mg} / 100 \mathrm{ml})$ & $\begin{array}{r}0 \\
15 \\
30 \\
45 \\
60\end{array}$ & $\begin{array}{l}118 \pm 6 \\
121 \pm 7 \\
120 \pm 5 \\
127 \pm 7 \\
132 \pm 11\end{array}$ & $\begin{array}{c}115 \pm 6 \\
410 \pm 35^{\mathrm{c}} \\
777 \pm 53^{\mathrm{c}} \\
1030 \pm 85^{\mathrm{c}} \\
1140 \pm 75^{\mathrm{c}}\end{array}$ & & $\begin{array}{c}118 \pm 6 \\
603 \pm 55^{\circ} \\
710 \pm 64 \\
946 \pm 69 \\
1045 \pm 58\end{array}$ & \\
\hline Free fatty acids $(\mathrm{mg} / 100 \mathrm{ml})$ & $\begin{array}{r}0 \\
15 \\
30 \\
45 \\
60\end{array}$ & $\begin{array}{l}11 \pm 0.7 \\
11 \pm 1 \\
13 \pm 2 \\
16 \pm 3 \\
15 \pm 2\end{array}$ & $\begin{array}{l}12 \pm 0.7 \\
18 \pm 1.4 \\
22 \pm 1.2 \\
22 \pm 1.5 \\
25 \pm 1.8\end{array}$ & $\left.\right|^{\mathrm{NS}}$ & $\begin{array}{l}12 \pm 1.1 \\
21 \pm 2 \\
20 \pm 1 \\
21 \pm 1.6 \\
21 \pm 1.2\end{array}$ & $\left.\right|^{\text {NS }}$ \\
\hline Phospholipids (mg/100 ml) & $\begin{array}{r}0 \\
15 \\
30 \\
45 \\
60\end{array}$ & $\begin{array}{l}76 \pm 5 \\
81 \pm 6 \\
82 \pm 7 \\
93 \pm 11 \\
95 \pm 13\end{array}$ & $\begin{array}{c}80 \pm 5 \\
200 \pm 17^{c} \\
340 \pm 25^{\mathrm{c}} \\
400 \pm 27^{\mathrm{c}} \\
425 \pm 32^{\mathrm{c}}\end{array}$ & & $\begin{array}{c}71 \pm 3 \\
266 \pm 23^{a} \\
323 \pm 27 \\
374 \pm 29 \\
466 \pm 26\end{array}$ & \\
\hline Total cholesterol $(\mathrm{mg} / 100 \mathrm{ml})$ & $\begin{array}{r}0 \\
15 \\
30 \\
45 \\
60\end{array}$ & $\begin{array}{l}33 \pm 2 \\
31 \pm 3 \\
35 \pm 6 \\
41 \pm 7 \\
47 \pm 11\end{array}$ & $\begin{aligned} 31 & \pm 2 \\
400 & \pm 45^{\mathrm{c}} \\
925 & \pm 75^{\mathrm{c}} \\
1330 & \pm 75^{\mathrm{c}} \\
1375 & \pm 95^{\mathrm{c}}\end{aligned}$ & & $\begin{aligned} 32 & \pm 1 \\
555 & \pm 43^{\mathrm{c}} \\
767 & \pm 70 \\
1014 & \pm 72 \\
1147 & \pm 63^{\mathrm{a}}\end{aligned}$ & \\
\hline Glucose $(\mathrm{mg} / 100 \mathrm{ml})$ & $\begin{array}{r}0 \\
15 \\
30 \\
45 \\
60\end{array}$ & $\begin{array}{l}135 \pm 3 \\
131 \pm 4 \\
137 \pm 3 \\
129 \pm 2 \\
133 \pm 4\end{array}$ & $\begin{array}{l}132 \pm 2 \\
138 \pm 2 \\
133 \pm 4 \\
128 \pm 3 \\
138 \pm 3\end{array}$ & NS & $\begin{array}{l}141 \pm 3 \\
138 \pm 3 \\
138 \pm 3 \\
132 \pm 4 \\
134 \pm 4\end{array}$ & NS \\
\hline
\end{tabular}

The number of animals in each group is indicated in brackets. The values for the plasma lipids and glucose are expressed as mean \pm SEM The degree of significance is calculated for cholesterol group vs control and cholesterol + gliclazide group vs cholesterol group ${ }^{\mathrm{a}} \mathrm{p} \leqslant 0.05{ }^{\mathrm{b}} \mathrm{p} \leqslant 0.01 \quad{ }^{\mathrm{c}} \mathrm{p} \leqslant 0.001$

Table 2. Effects of gliclazide on the lipid content of the liver of rabbits given cholesterol

\begin{tabular}{|c|c|c|c|c|c|c|}
\hline \multirow[t]{3}{*}{ Biochemical analysis } & \multicolumn{6}{|l|}{ Group } \\
\hline & \multicolumn{2}{|c|}{ Normal control [18] } & \multicolumn{2}{|c|}{ Cholesterol fed rabbits [18] } & \multicolumn{2}{|c|}{$\begin{array}{l}\text { Cholesterol fed rabbits } \\
+ \text { gliclazide }[16]\end{array}$} \\
\hline & $\begin{array}{l}\mathrm{mg} / 100 \mathrm{~g} \\
\text { wet wt }\end{array}$ & $\begin{array}{l}\mathrm{mg} / \mathrm{kg} \\
\text { body wt }\end{array}$ & $\begin{array}{l}\mathrm{mg} / 100 \mathrm{~g} \\
\text { wet wt }\end{array}$ & $\begin{array}{l}\mathrm{mg} / \mathrm{kg} \\
\text { body wt }\end{array}$ & $\begin{array}{l}\mathrm{mg} / 100 \mathrm{~g} \\
\text { wet wt }\end{array}$ & $\begin{array}{l}\mathrm{mg} / \mathrm{kg} \\
\text { body wt }\end{array}$ \\
\hline Total fatty acids & $3550 \pm 300$ & $1050 \pm 30$ & $6300 \pm 300^{c}$ & $2010 \pm 100^{c}$ & $5850 \pm 300$ & $1800 \pm 100$ \\
\hline Phospholipids & $4015 \pm 70$ & $1010 \pm 50$ & $4400 \pm 500^{c}$ & $1400 \pm 50$ & $4420 \pm 130$ & $1360 \pm 40$ \\
\hline $\begin{array}{l}\text { Total cholesterol } \\
\text { Cholesterol esters. } \\
\text { Free cholesterol }\end{array}$ & $\begin{array}{c}315 \pm 10 \\
55 \pm 5 \\
260 \pm 25\end{array}$ & $\begin{array}{l}80 \pm 3 \\
20 \pm 3 \\
60 \pm 2\end{array}$ & $\begin{array}{l}3810 \pm 160^{c} \\
2630 \pm 150^{c} \\
1180 \pm 70^{c}\end{array}$ & $\begin{array}{r}1215 \pm 60^{c} \\
835 \pm 50^{\circ} \\
380 \pm 25^{\mathrm{c}}\end{array}$ & $\begin{array}{l}2780 \pm 205^{c} \\
1726 \pm 99^{c} \\
1029 \pm 96\end{array}$ & $\begin{array}{l}865 \pm 72^{c} \\
537 \pm 38^{c} \\
320 \pm 34\end{array}$ \\
\hline Glycerides & $1330 \pm 100$ & $340 \pm 20$ & $2950 \pm 200^{c}$ & $950 \pm 70^{c}$ & $2810 \pm 320$ & $860 \pm 100$ \\
\hline Liver wt as $\%$ body wt & \multicolumn{2}{|c|}{$2.50 \pm 0.05$} & \multicolumn{2}{|c|}{$3.20 \pm 0.10^{\mathrm{c}}$} & \multicolumn{2}{|c|}{$3.05 \pm 0.10$} \\
\hline
\end{tabular}

The number of animals in each group is indicated in brackets. The values for the hepatic lipids are expressed as mean \pm SEM The degree of significance is calculated for cholesterol group vs controls and cholesterol + gliclazide group vs cholesterol group ${ }^{c} p \leqslant 0.001$

ques' permitted assessment of the extent of such lesions. The endothelial cells were little affected, resting on a sub-endothelial space consisting of cells packed with lipids, the 'foam cells' or 'xanthoma cells', and numerous fibres of collagen; the internal elastic limiting membrane was fragmented; the internal zone of the tunica media consisted of smooth muscle cells invaded by lipids, scattered elastic elements and disordered collagen fibres. The external zone of the tunica media and the adventitious tunica 
Table 3. Effects of gliclazide on the aortic lipids of rabbits given cholesterol

\begin{tabular}{llll}
\hline Biochemical analysis & Group & & \\
\cline { 2 - 4 } & normal & Choles- & Cholesterol \\
& control & terol fed & fed rabbits \\
& {$[18]$} & rabbits & + Gliclazide \\
& & {$[18]$} & {$[16]$}
\end{tabular}

\section{Total fatty acids}

$\mathrm{mg} / 100 \mathrm{~g}$

wet wt

$1870 \pm 10 \quad 3030 \pm 140^{c} \quad 2100 \pm 100^{c}$
Phospholipids

$\mathrm{mg} / 100 \mathrm{~g}$

wet wt

Cholesterol $\int$ Total

$\mathrm{mg} / 100 \mathrm{~g}$
wet wt $\left\{\begin{array}{l}\text { Esterified } \\ \text { free }\end{array}\right.$

Glycerides

$\mathrm{mg} / 100 \mathrm{~g}$

wet wt

$\begin{array}{ccc} & & \\ 565 \pm 20 & 1051 \pm 43^{\mathrm{c}} & 1080 \pm 43 \\ 151 \pm 5 & 1225 \pm 130^{\mathrm{c}} & 1085 \pm 138 \\ 9 \pm 1.5 & 885 \pm 115^{\mathrm{c}} & 695 \pm 135 \\ 142 \pm 4.5 & 340 \pm 31^{\mathrm{c}} & 390 \pm 55 \\ & & \\ 1650 \pm 70 & 2260 \pm 140^{\mathrm{b}} & 1280 \pm 90^{\mathrm{c}}\end{array}$

The number of animals in each group is indicated in brackets. The values for the aortic lipids are expressed as mean \pm SEM

The degree of significance is calculated for cholesterol group vs controls and cholesterol + gliclazide group vs cholesterol group

${ }^{b} \mathrm{p} \leqslant 0.01 \quad{ }^{\mathrm{c}} \mathrm{p} \leqslant 0.001$
Table 5. Effect of gliclazide on the histological appearance of the thyroid gland of rabbits given cholesterol

\begin{tabular}{llll}
\hline Group & $\begin{array}{l}\text { Normal con- } \\
\text { trol [18] }\end{array}$ & $\begin{array}{l}\text { Cholesterol } \\
\text { fed rabbits } \\
{[18]}\end{array}$ & $\begin{array}{l}\text { Cholesterol fed } \\
\text { rabbits }+ \text { gli- } \\
\text { clazide [16] }\end{array}$ \\
\hline $\begin{array}{l}\text { Index of thyroid } \\
\text { activity }\end{array}$ & $2 \pm 0.019$ & $3.67 \pm 0.039^{c}$ & $2.4 \pm 0.033^{\mathrm{c}}$ \\
\hline
\end{tabular}

All animals were sacrificed at 60 days

Thyroid activity has been assessed according to Kampelmann's scale

The number of animals in each group is shown in brackets. The values for the index of thyroid activity are expressed as mean \pm SEM

The degree of significance is calculated for cholesterol group vs controls and cholesterol + Gliclazide group vs cholesterol group c $\mathrm{p}<0.001$

Table 4. The degree of atherosclerosis in the aorta of rabbits treated with cholesterol alone - effects of gliclazide

\begin{tabular}{|c|c|c|c|}
\hline \multicolumn{2}{|c|}{ Arterial pathology (Degree of atherosclerosis) } & \multicolumn{2}{|l|}{ Group } \\
\hline \multirow{3}{*}{ Macroscopic examination } & Aortic arch & $3.7 \pm 0.1$ & $3.0 \pm 0.3$ \\
\hline & Thoracic aorta & $3.1 \pm 0.2$ & $1.9 \pm 0.3^{b}$ \\
\hline & Abdominal aorta & $1.8 \pm 0.2$ & $1.0 \pm 0.2^{\mathrm{b}}$ \\
\hline \multirow{4}{*}{ Microscopic examination } & Aortic arch & $3.1 \pm 0.2$ & $2.2 \pm 0.2^{b}$ \\
\hline & Thoracic aorta & $2.4 \pm 0.2$ & $1.1 \pm 0.2^{\mathrm{c}}$ \\
\hline & Abdominal aorta & $1.2 \pm 0.3$ & $0.6 \pm 0.2$ \\
\hline & Coronary arteries & $1.8 \pm 0.3$ & $0.6 \pm 0.2^{\mathrm{b}}$ \\
\hline
\end{tabular}

All animals were sacrificed at 60 days. There were no lesions of aorta in normal controls, except at the level of the arch of the aorta where there were sometimes lipidic patches

The number of animals in each group is indicated in brackets. The values for the degree of atherosclerosis are expressed as mean $\pm \mathrm{SEM}$ The degree of significance is calculated for cholesterol + gliclazide group vs cholesterol group

${ }^{b} \mathrm{p}<0.01 \quad \mathrm{c} p<0.001$

presented a normal appearance. Moréover, examinations involving the coronary artery showed evidence of local sub-endothelial accumulation of foam cells, the underlying tunica media being frequently modified. The lesions were particularly clear around the small coronary vessels; these minor ramifications were partially or completely occluded by the hyperplasia of the tunica intima.

Thyroid Histology: In the control rabbits, sustained thyroid activity was observed; the vesicles were of small diameter, colloid very sparse, the epithelium prismatic, the nuclei rounded and located half way up the cell and acidophilia was weak. This histological appearance of the gland corresponds to the stage 2 of Kamplemann's scale. In the animals treated with cholesterol for 60 days, the thyroid vesicles were of medium size, sometimes large, the colloid abundant and acidophilic, the cells of the thyroid epithelium flat and their nuclei oval and attached to the base. The greatly diminished thyroid activity of these hypercholesterolaemic animals. although there were fairly marked individual differences, corresponded to stages 3 and 4 of Kamplemann's scale (Table 5). 
Effect of Cholesterol Rich Diet + Gliclazide

After treatment with gliclazide at the low-doses used ( $10 \mathrm{mg} / \mathrm{kg} /$ day) plasma glucose values were unchanged in the non-fasted animals (Table 1).

Plasma and Liver Lipids: At the 15th day, gliclazidetreated animals had a significant increase in plasma lipids.

Thereafter there were no significant modification of lipid components except for total cholesterol which was decreased on the 60th day of treatment (Table 1). With regard to the liver, no changes were observed in the content of triglycerides or phospholipids. However, it was noted that the addition of gliclazide to the diet rich in cholesterol greatly reduced the hepatic accumulation of cholesterol esters (Table 2). All these values, although lower than the high cholesterol values were still vastly greater than in the animals on a normal diet.

Arterial Lipids: Gliclazide had a most noticeable prophylactic effect on the entire arterial trunk. Biochemical analysis revealed that the aortic lipid content was reduced significantly (Table 3 ); for the entire group of animals treated with gliclazide, the mean content of total fatty acids was only slightly higher that the normal values. The glycerides were likewise affected; but the cholesterol fractions were only slightly decreased.

Arterial Pathology: Macroscopic examination showed that the arterial lesions were also greatly diminished in relation to those in cholesterol fed animals. The presence was noted of papules, isolated or rosary like but these were rarely in the form of patches (e.g. an index of $1.9 \pm 0.3$ as compared to $3.1 \pm 0.2$ at the level of the thoracic aorta); in some animals no change could be detected over a large part of the aortic trunk.

The favourable results were largely confirmed at the histopathological level. In most cases, degenerative changes in the superficial elastic fibres were observed with sometimes a few conjunctival hyperplastic reactions which are the initial stages of development of atherosclerosis (Table 4). The lipophages were likewise very small in number in the sub-endothelial space. Gliclazide had a particular prophylactic effect on the coronary arteries, which had a normal appearance in more than $50 \%$ of cases. In the other animals, the hyperplastic intimal reactions were always limited and the absence of foam cells was more or less general while in the cholesterol-treated rabbits most of the secondary ramifications were partially or completely occluded.
Thyroid Histology: Finally, with regard to the thyroid gland, it was noted that in those animals in which activity was partly maintained (stages 2 and 3 of Kampelmann's scale; Table 5), the supranuclear cytoplasm remained large, the vesicles were relatively reduced and the colloid was somewhat sparse.

\section{Discussion}

Gliclazide administration to rabbits fed a high cholesterol diet induced a marked decrease of atheromatous lesions without noticeable effects on plasma lipids. Interpretation of the transient rise in plasma lipids observed on the 15th day is difficult. Thereafter, gliclazide did not produce any consistent modification of the high-cholesterol-diet-induced lipid disturbances.

This is an agreement with the work of SmitSibinga and Wieringa [31] who observed no effect on serum cholesterol in rabbits at a dose level of $15 \mathrm{mg} /$ $\mathrm{kg}$. According to these authors, hypercholesterolaemia is only seen at hypoglycaemic doses e.e. $25 \mathrm{mg} / \mathrm{kg}$.

However, treatment with gliclazide in the present experiments did significantly reduce the hepatic accumulation of cholesterol by up to $34 \%$ in relation to control values. To our knowledge, this effect on hepatic cholesterol metabolism has not been reported for other hypoglycaemic sulphonamides. Although further research is being undertaken into the mechanism of this action, it may be worthwhile at this stage to speculate on the possible involvement of thyroid gland function.

Earlier sulphonamides slow-down thyroid activity; on the contrary, gliclazide maintained noticeable histological thyroid activity, but measurements of levels of circulating thyroid hormones are necessary to confirm histology data. Since thyroxine is known to promote greatly the biliary excretion of cholesterol metabolites [9] and increase synthesis [11]; it is possible that gliclazide counteracted hepatic cholesteatosis by promoting thyroid activity. This hypothesis must be studied.

The patterns of arterial lesions in cholesterol-fed rabbits are altogether in agreement with the many descriptions in the literature. In previous studies we showed that gliclazide could forestall the atherosclerotic syndrome [22]. The present results confirm this, demonstrating that in the aorta accumulation of glycerides and fatty acids was significantly reduced and the severity of atherosclerotic lesions throughout the arterial trunk considerably diminished (both at the macroscopic and microscopic levels) following administration of the drug. These results are sup- 
ported by work on another experimental model of atheroma in which gliclazide prevented arterial infiltration of lipids following local irradiation and treatment with cholesterol [31]. The present experiments also showed that in more than $50 \%$ of the animals treated with gliclazide the histological appearance of the coronary arteries was completely normal in contrast to the cholesterol treated controls where most of the coronary ramifications were partially or totally occluded. These antiatheromatous properties were not related to the level of plasma lipids, suggesting a vascular metabolic effect of the drug. It must be stressed that earlier reports of studies performed with old sulphonamides revealed both an increase of lipid disorders and of vascular lesions, especially of the coronary arteries in the chicken $[16,29]$ and the rabbit $[23,24]$.

The experimental model uses a normoglycaemic animal. Abnormal glucose tolerance test appears after longer cholesterol administration [25].

From our results, low gliclazide dose does not induce significant modification in plasma glucose in fed animals. A dynamic study of plasma immunoreactive insulin may be helpful, but the relationship between insulin levels, diabetes, hyperlipaemia and atheroma are unclear. Data from studies performed with gliclazide do not indicate a direct relationship between hypoglycaemic and anti-atheromatous properties.

Results of studies in progress with diabetic rabbits and psammomys obesus could help to elucidate the mechanism of action of gliclazide.

Several other pharmacological effects could be involved in these antiatherogenic properties. This sulphonamide has been shown to reduce markedly platelet adhesiveness [6] to decrease strongly platelet aggregation (by an inhibition of platelet ADP release [33], to enhance fibrinolysis [5] and to reduce the exaggerated vasoconstrictor responses to adrenaline in experimental diabetes [7, 8]. All these actions could influence to varying degrees the preventive effect of the drug on aortic and coronary atherosclerosis.

In conclusion, our study indicates that gliclazide, at the low-doses used, reduced the accumulation of cholesterol in the liver and strongly inhibited the development of aortic and particularly coronary lesions induced by the cholesterol rich diet. But the mechanism of action of gliclazide is unclear.

\section{References}

1. University Group Diabetes Program: A study of the effects of hypoglycaemic agents on vascular complications in patients with adult-onset diabetes: I - Design, methods and baseline results. Diabetes 19 (Suppl. 2), 747-783 (1970)
2. University Group Diabetes Program: A study of the effects of hypoglycaemic agents on vascular complications in patients with adult-onset diabetes: II - Mortality results. Diabetes 19 (Suppl. 2), 787-830 (1970)

3. Albrink, M.J.: The microtitration of total fatty acids of serum with notes on the estimation of triglycerides. J. Lipid Res. 1, 53-59 (1959)

4. Delsal, J. L., Manhouri, M.: Etude comparative des dosages colorimétriques du phosphore. Recherche d'une méthode de haute sensibilité applicable au dosage du phosphore organique dans les spots après chromatographie. Bull. Soc. Chim. Biol. 9-10, 1041-1054 (1955)

5. Desnoyers, P., Labaume, J., Baudet, M., Verry, M.: Fibrinolytic activity of vascular endothelium, demonstrated by Todd's method after administration of a new antidiabetic drug: 1702 SE. 2nd Congress of the International Society of Thrombosis and Haemostasis, 12-16 th July, 1971, Oslo

6. Desnoyers, P., Labaume, J., Anstett, M., Herrera, M., Pesquet, J., Sebastien, J.: The pharmacology of 1702 SE, a new highly effective antidiabetic drug with unusual properties. III - Antistickiness activity fibrinolytic properties and haemostatic parameters study. Arzneim. Forsch. 22, 1691-1695 (1972)

7. Duhault, J., Desnoyers, P., Bérégi, L., Hugon, P.: Pharmacological approaches to the treatment of diabetes. Diabetologia 6, 43 (Abstract) 1970

8. Duhault, J., Lebon, F., Bérégi, L.: Protective action of 1702 $\mathrm{SE}$ on the microvascular system in the normal and diabetic rats. Diabetes 20 (Suppl. 1), 353 (1971)

9. Ericksson, S.: Influence of thyroid activity on excretion of bile acids and cholesterol in the rat. Proc. Soc. Exp. Biol. Med. 94, 582-584 (1957)

10. Fiske, C. H., Subbarow, Y.: The coloric determination of phosphorus. J. Biol. Chem. 66, 375-400 (1925)

11. Fletcher, K., Myant, N.B.: Influence of the thyroid on the synthesis of cholesterol by liver and skin in vitro. J. Physiol. (Lond.) 144, 361-372 (1958)

12. Folch, J., Lees, M., Stanley, G.H. S.: A simple method for the isolation and purification of total lipids from animal tissues. J. Biol. Chem. 226, 497-509 (1957)

13. Gendre, P.: Evolution de l'ultrastructure de l'atherome cholesterique experimental chez le lapin. Pathol. Eur. 4, 235-256 (1969)

14. Hanno, G., Awwad, H. K.: A study of the antithyroid effect of tolbutamide. Endocrinology 25, 343-350 (1962)

15. Hartel, G.: Úber die Bedeutung der Schilddrüse für das Auftreten von erhöhten Serumcholesterinwerten bei Ratten nach Fütterung von $\mathrm{N}_{1}$-sulfanilyl- $\mathrm{N}_{2}$-n-butylcarbamid (BZ 55) Acta Endocrinol. (Kbh.) 29, 267-270 (1958)

16. Hartel, G., Punsar, S., Louhija, A.: Die Wirkung hoher Dosen von $\mathrm{N}_{1}$-sulfanilyl- $\mathrm{N}_{2}$-n-butylcarbamid auf die Regression experimenteller Atherosklerose, auf spontane Atherosklerose und auf Serumcholesterinwerte bei Hähnchen. Arzneim. Forsch. 8, 301-304 (1958)

17. Havel, R. J., Felts, J.M., Van Duyne, C. M.: Formation and fate of endogenous triglycerides in blood plasma of rabbits. J. Lipid Res. 3, 297-308 (1962)

18. Kampelmann, F.: Über die Wirkung von arseniger Säure auf die Schilddrüse und den Hypophysenvorderlappen. Arch. Exp. Pathol. Pharmakol. 184, 139-151 (1937)

19. Keen, G., Jarrett, R. J.: Tolbutamide prophylaxis of arterial disease in borderline diabetics. Diabetes 17 (Suppl. 1), 328-332 (1968)

20. Landriscina, C., Gnoni, G. V., Quagliariello, E.: Fatty acids biosynthesis: Physiological role of the elongation system present in microsomes and mitochondria of rat liver. Eur. J. Biochem. 29, 188-196 (1972) 
21. Laurell, S., Tibbling, G.: Colorimetric microdetermination of free fatty acids in plasma. Clin. Chim. Acta 16, 57-62 (1966)

22. Marquié, G.: Effets préventifs du gliclazide sur le développement de l'athérosclerose induite par le cholestérol chez le lapin. C. R. Acad. Sci. [D] (Paris) 175, 197-200 (1977)

23. Marquié, G., Agid, R.: Effets de certains sulfamides hypoglycémiants sur le développement de l'athérome expérimental induit par le cholestérol chez le lapin. J. Physiol. (Paris) 59, 262 (1967)

24. Marquié, G., Agid, R.: Effets d'un sulfamide hypoglycémiant sur la régression des troubles lipidiques et l'évolution des lésions artérielles chez le lapin après cessation du régime riche en cholestérol. C. R. Soc. Biol. (Paris) 165, 192-196 (1971)

25. Marquié, G., Agid, R.: Influence d'un régime riche en cholestérol sur l'activité du pancréas endocrine du lapin. Gen. Comp. Endocrinol. 18, 113 A (1972)

26. Marquié, G., Agid, R.: Effets de la metformine (NN-diméthylbiguanide) sur l'hypothyroidie et l'infiltration lipidique du cortex surrénal, induites par le régime cholestérolé chez le lapin. Pathol. Biol. (Paris) 21, 133-139 (1973)

27. Miller, B.F., Kothari, H. V.: Increased activity of lysosomal enzymes in human atherosclerotic aortas. Exp. Mol. Pathol. 10, 288-294 (1969)

28. Paasikivi, J., Wahlberg, F.: Preventive tolbutamide treatment and arterial disease in mild hyperglycaemia. Diabetologia 7 , 323-327 (1971)

29. Punsar, S., Hartel, G.: Über den Einfluß von $N_{1}$-n-sulfanilyl-
$\mathrm{N}_{2}$-n-butylcarbamid auf die experimentelle Atherosklerose bei Hähnchen. Ann. Med. Exp. Biol. Fenn. 35, 189-197 (1957)

30. Somogyi, M.: Notes on sugar determination. J. Biol. Chem. 195, 19-23 (1952)

31. Smit-Sibinga, C.T., Wieringa, R. A.: The effect of gliclazide on irradiation induced experimental atheromatosis. 1st World Congress on Microcirculation, 18th June 1975, Toronto, Canada. Proceedings in press - Plenum Press, N. Y.

32. Sperry, W.M., Brand, F.: Determination of total lipids in blood serum. J. Biol. Chem. 213, 69-76 (1955)

33. Verry, M., Desnoyers, P., Thouverez, J. P.: Activité anti-adhesive plaquettaire d'un nouvel antidiabétique, le $1702 \mathrm{SE}$. 2nd Mediterranean Congress on Thromboembolism, 11-14th October 1971, Istanbul

Received: May 30, 1977,

and in revised form: December 13, 1977

Dr. G. Marquié

Department of Nutrition

Institute of Biology

University of Science and Technology

P. O. Box 9

Dar-el-Beida

Algiers

Algeria 